\title{
Production of Bovine Transgenic Embryos by Microinjection of a Lentiviral Vector in Mature Ovocytes
}

\author{
Rafael Otero ${ }^{1}$, Darwin Hernández ${ }^{*}$ and Luiz Sergio de A Camargo ${ }^{2}$ \\ 'Universidad de Sucre - Campus Ciencias Agropecuarias, Sincelejo, Colombia; darwin.hernandez@unisucre.edu.co \\ Embrapa Dairy Cattle Research Center, Juiz de Fora, MG, Brazil
}

\begin{abstract}
Objective: To produce bovine transgenic embryos by microinjection of a lentiviral vector with the eGFP gene as a marker. Methods: Four treatments were designed: T1=Control: fertilized in vitro (FIV) with cumulus-oocyte complexes (CCOs), cultivated in CR2 medium with $10 \% \mathrm{FBS}$ and incubated at $38.5^{\circ} \mathrm{C}$ in an atmosphere of $95 \%$ humidity and $5 \% \mathrm{CO}_{2}$. T2=Control of culture medium: CCOs removed by vortex in the presence of hyaluronidase, FIV, grown in SOF medium in hermetic bag, with a gaseous mixture of $5 \% \mathrm{CO}_{2}, 5 \% \mathrm{O}_{2}$ and $90 \% \mathrm{~N}_{2}$ and humidity saturated at $38.5^{\circ} \mathrm{C}$. T3=Microinjection control: $\mathrm{CCOs}$ removed microinjected with TALP medium, FIV and cultured under the same treatment conditions T2. T4=Microinjected with the lentivirus: CCOs removed microinjected with the lentiviral vector and FIV and cultured in the same conditions of the T2 and T3 treatments. The rate of development of blastocysts at day eight and the expression of the eGFP gene were evaluated. Findings: No significant statistical differences were found $(p>0.05)$ in the production of blastocysts at day eight, between treatments T1, T2, and T3. The percentage of blastocysts found in the T4 treatment was significantly lower $(\mathrm{p}<0.05)$ than in the other treatments. All embryos obtained in T4 expressed the transgene of interest. Application / Improvements: It is concluded that the culture conditions used were adequate for T1, T2 and T3, added that the microinjection with the lentiviral vector influences in some way the embryonic development, although, the technique was highly efficient for obtaining transgenic embryos.
\end{abstract}

Keywords: Genetic Modification, Green Fluorescent Protein (eGFP), Micromanipulation

\section{Introduction}

Genetically Modified Organisms (GMOs) or transgenic organisms are organisms that by human action have DNA sequences of another species inserted in their genome $e^{1}$. The gene that is introduced basically, is a construction that contains the promoter and coding region of the protein of interest, this fragment is commonly called a transgene and can be of animal, bacterial or plant origin $n^{2,3}$. Therefore the transgenic term is defined as the introduction, alteration or inactivation of a gene sequence in the genome of multicellular organisms, these changes being capable of being transmitted to the progeny ${ }^{2}$.
Transgenic Animals (TA) can be used for the production of recombinant human proteins, xenotransplantation, in vivo study of the function of a gene during organogenesis, development, and aging; the generation of experimental models in animals for the knowledge of the mechanisms involved in the development of diseases, as well as the study of therapeutic strategies in models of diseases in humans $\frac{4-6}{}$. In animal production, this technique supports breeding programs with rapid multiplication of animals with desirable characteristics and economic interest ${ }^{\underline{T}}$.

Among the different biotechnical manipulation, several methods can be used for the generation of $\mathrm{TA}^{\stackrel{8}{ }}$,

*Author for correspondence 
among them: pronuclear microinjection" ${ }^{2}$, DNA transfer mediated by sperm, nuclear transfer from transfected somatic cells (SCNT) $)^{10}$ pronuclear DNA microinjection ${ }^{11}$, microinjection of transposons $\frac{13}{3}$, and the retroviral vectors ${ }^{4}$.

When retroviral vectors are used, lentiviruses are the most used ${ }^{4}$, especially those developed from the genome of the Human Immunodeficiency Virus type-1 (HIV-1) since they do not possess the viral genes, in order to minimize the risk of virus formation by competent replication, by eliminating dispensable genes for the gene transfer of the virus, such as the Vpu gene, and the activation of the promoter regions in the viral genome (LTR $\left.5^{\prime}\right)^{14}$. Thus, retroviral vectors are obtained by replacing the trans sequences, that is, the three viral genes (gag, pulg and env) are replaced by one or more genes, whereas, the set of $c i s$ sequences, that is, the necessary regulatory sequences for encapsulation (sequence $\psi$ ), reverse transcription (PBS, $\mathrm{R}, \mathrm{PPT}$ ) and gene expression (LTR) are retained in this process $^{4,15}$.

One of the most used transgenes is the Green Fluorescent Protein (eGFP) derived from the jellyfish Aequorea victoria ${ }^{16}$ that has been widely used as a marker gene in transgenic animals since it shows a stable expression in mammalian cells, which can track in situ quantitatively or qualitatively and non-invasively ${ }^{17}$.

The first transgenic animals generated using lentiviral vector technology were developed by ${ }^{18}$, in this research the authors suggest that the injection of lentiviral vectors derived from the human immunodeficiency virus (HIV-1) in the perivitelline space of fertilized oocytes could increase significantly the production efficiency of transgenic animals. Then, the comparison of the classic DNA microinjection technique with the transfer of genes in a lentiviral vector resulted in a four to eight times the higher rate ${ }^{19}$. Today the technique has been massed to different animals ${ }^{13}$, although, there are still some limitations to the use of lentiviruses, especially when it is necessary to use high viral titers, since the lentivirus must surpass the zona pellucida (ZP) of the embryo and the extracellular glycoprotein matrix that confers external protection to the embryo ${ }^{20}$ even against infectious agents $s^{21}$. However, in this case, the ZP ends up acting as a physical barrier that prevents the penetration of the lentivirus ${ }^{20}$. Therefore, the preferred method for the injection of viral particles is within the perivitelline space (subzonal injection) allowing the virus to overcome the membrane of the oocyte or the zygote. What makes necessary sophisticated equipment for subzonal injection (inverted microscope, manipulators, and microinjectors $)^{20}$.

The objective of this study is to produce bovine transgenic embryos by microinjection of a lentiviral vector that carries the eGFP gene as a marker in mature oocytes.

\section{Materials and Methods}

\subsection{Collection of the Ovaries and Manipulation of the Oocytes}

In this investigation, 360 ovaries were collected in bovine females, without defining the breed in a different phase of the estrus cycle, slaughtered in a cold storage facility located in the city of Juiz de Fora, Minas Gerais, Brazil. Immediately after sacrifice and evisceration, the ovaries were removed and immersed in a thermal carafe with physiological solution $(0.9 \% \mathrm{NaCl})$ increased with streptomycin sulfate $(0.05 \mathrm{~g} / \mathrm{L})$, at a temperature between $35-38^{\circ} \mathrm{C}$. At the end of the collection, the ovaries were transported to the animal reproduction laboratory in a maximum time of thirty minutes. The ovaries were washed with physiological solution, previously placed in a water bath at $37^{\circ} \mathrm{C}$; the ovarian follicles $(\leq 10 \mathrm{~mm})$ were suctioned with a syringe. The follicular fluid was deposited in a conical calyx, at a temperature of $37^{\circ} \mathrm{C}$. Once decanting of the oocytes occurred, they were resuspended in TALP-HEPES medium, after removal of the supernatant fluid and transferred to Petri dish, on the heating plate at $37^{\circ} \mathrm{C}$ and then classified morphologically, according to ${ }^{22}$. Only immature oocytes classified as cells of compact acumulus and with at least three cell layers were transferred to a third Petri dish containing TALP-HEPES medium, and subsequently used in the experimental procedures.

\subsection{In vitro Maturation (IVM)}

We used 834 immature oocytes, which were matured in TCM 199 medium (Tissue Culture Medium 199) (Gibco/ Invitrogen) supplemented with FSH (Follicle Stimulating Hormone) $(20 \mu \mathrm{g} / \mathrm{ml})$ and cow serum in heat $(10 \%)$. The maturation was carried out in groups of 50-60 structures, deposited in plates Nunc (Thermo Scientific, Cat.176740) of four wells, containing $400 \mu \mathrm{l}$ of maturing medium previously balanced for at least two hours in cell culture incubator at $38.5^{\circ} \mathrm{C}$ with an atmosphere of $95 \%$ humidity, and $5 \% \mathrm{CO}_{2}$. The oocytes were cultured under these conditions of temperature and atmosphere for 22 to 24 
hours. After being matured, they were distributed in four treatments.

\subsection{Treatments}

Four treatments were designed, as follows: $\mathbf{T 1}=$ Control: Fertilized in vitro with cumulus-oocyte complexes (CCOs) with a concentration of $1 \times 10^{6}$ spermatozoa $(\mathrm{SPTZ}) / \mathrm{ml}$, cultured in CR2 medium enriched with $10 \%$ FBS and incubated at $38.5^{\circ} \mathrm{C}$ in an atmosphere of $95 \%$ humidity and $5 \% \mathrm{CO}_{2}$. T2 = Control of culture medium: Cumulus cells removed by vortex in the presence of hyaluronidase, fertilized in vitro with a concentration of $1 \times 10^{6}$ spermatozoa (SPTZ) $/ \mathrm{ml}$, grown in SOF medium in aluminum sachets with a gas mixture of $5 \% \mathrm{CO}_{2}, 5 \% \mathrm{O}_{2}$ and $90 \% \mathrm{~N}_{2}$ and saturated humidity at a temperature of $38.5^{\circ} \mathrm{C} . \mathbf{T 3}=$ Microinjection control: Cumulus cells removed by vortex in the presence of hyaluronidase, microinjected with TALP medium and then fertilized in vitro at a concentration of $1 \times 10^{6}$ spermatozoa (SPTZ) $/ \mathrm{ml}$, and cultured under the same treatment conditions T2. T4 = Microinjected with the lentivirus: Cumulus cells removed by vortex in the presence of hyaluronidase microinjected with the lentiviral vector and then fertilized in vitro at a concentration of $1 \times 10^{6}$ spermatozoa (SPTZ)/ml, and cultured under the same conditions of the $\mathrm{T} 2$ and $\mathrm{T} 3$ treatments.

\subsection{Lentiviral Vector}

The lentiviral vectors were produced by transient transfection, using four plasmids: the packaging plasmid (pMDLg / pRRE), which encodes the envelope protein (pMD2.G), the plasmid that encodes the Rev protein (pRSV-Rev) (Addgene, USA) and the plasmid containing the transgene (pLGW).

Cell lineage HEK-293F (ATCC CRL 1573) cultured in DMEM medium was used more than 10\% FBS until reaching the $80 \%$ confluency state. Transfection with the lentiviral vectors was performed with a mixture containing the four plasmids, in concentrations of $6 \mu \mathrm{g}$ of DNA from each of the structural plasmids (pMDLg / pRRE, pMD2.G, and pRSV-Rev) and $12 \mu \mathrm{g}$ of the plasmid of interest (pLGW).

Two mixtures have been prepared separately: a mixture of $18 \mathrm{mM}$ polyethyleneimine (PEI, Sigma) plus 5\% glucose and another mixture of plasmid DNA plus 5\% glucose. The ratio of $1 \mu \mathrm{L}$ of PEI (with $\mathrm{pH}$ adjusted to 7 ) per $1 \mu \mathrm{g}$ of DNA was used. The two mixtures were vortexed for one minute and left to rest for 5 minutes, then both mixed and put into vigorous vortexing, all the contents were kept at rest for 10 minutes, during which time a new one was made. Medium exchange without SFB. $1 \mathrm{~mL}$ of DMEM without SFB was added to the mixture and, after homogenization, all the contents were added to the culture bottle. After 6 hours of transfection, SFB was added to the medium to obtain the concentration of $10 \%$. After 48 hours, the culture medium was centrifuged at $25000 \mathrm{rpm}$ for 1.5 hours at $4^{\circ} \mathrm{C}$. The lentivirus pellet was resuspended in $100 \mu \mathrm{L}$ of DMEM without SFB and frozen at $-80^{\circ} \mathrm{C}$ until used.

\subsection{Microinjection of Oocytes Pre- Fertilization with Lentiviral Vector}

After in vitro maturation, cumulus cells were removed from the oocytes by the addition of $0.1 \%$ hyaluronidase in vortex mechanical agitation for five minutes. Next, the tubes containing the naked oocytes were washed with TALP-HEPES medium. The evaluation of the nuclear maturation of the oocytes was made by observing the polar corpuscle using a stereoscope (Nikon SMZ 645), being those considered suitable and randomly distributed in the treatments. The oocytes were again washed in TALP medium and kept in drops of $20 \mu \mathrm{l}$ of the medium covered with mineral oil until the moment of microinjection.

The injection of the TALP medium and the lentiviral vector into the perivithelium space (subzonal) was done by direct observation in an inverted microscope (Axiovert 135M, Carl Zeiss) equipped with a hydraulic micromanipulation system (Nikon Narishige NT-88V3), connected to a microinjection system. The oocytes were immobilized with the fixation pipette and, with the loaded micro-needle; subzonal microinjection was performed with the TALP medium or with the solution containing the lentiviral vector, as appropriate. During manipulation, the zona pellucida expanded immediately, and the microinjection was considered successful when the zona pellucida grew visibly. After the injection of the TALP or the subzonal lentivirus, the oocytes were washed three times in TALP medium and again transferred to the TCM medium. During this period, the oocytes from the control treatments (not microinjected) remained in the TCM medium.

\subsection{In vitro Fertilization (IVF)}

The control and microinjected oocytes were transferred to fertilization drops with $100 \mu \mathrm{l}$ of FERT-TALP medium plus $10 \mathrm{UI} / \mathrm{mL}$ of heparin (Sigma), under mineral oil (approxi- 
mately 20 oocytes/drop). For fecundation, bull semen from the Gir breed was used, previously evaluated in terms of vigor, motility, and concentration. Only doses with motility equal to or greater than $50 \%$ and vigor at minimum 3 were used, so that throughout the experiment the same batch of semen from the same bull was used. The semen was thawed in a maria bath at $37^{\circ} \mathrm{C}$ for 30 seconds, the spermatozoa were processed by the Percoll gradient method (Nutricell) with the concentrations of $90 \%$ and $45 \%$ for separation of the motile spermatozoa in centrifugation, besides the removal of the diluent and seminal plasma. The Percoll gradient was previously prepared and stabilized in the incubator for 15 minutes before use. The semen was diluted, with a concentration adjusted to obtain a fertilizing dose of $1 \times 10^{6} \mathrm{sperm} / \mathrm{mL}$, and transferred to the fertilization drops (100 $\mu \mathrm{l}$ of FERT-TALP medium). The IVF process was carried out for 20 hours in a cell culture incubator, under the same conditions of oocyte maturation. The concentration $1 \times 10^{6}$ sperm $/ \mathrm{mL}$ was used because the cells of the cumulus were removed from the oocytes and by the procedure of the perforation of the ZP before fertilization, so it was sought not to cause a polyspermy.

\subsection{In vitro Culture (IVC)}

After fertilization, the presumed zygotes were removed from the drop of fertilization, washed in TALP-HEPES medium, and divided into two culture plates, where one was the control and the other the treatments.

In the $\mathrm{T} 1$ treatment, the supposed zygotes were subjected to the nakedness with the help of a pipettor and washed in TALP medium. The culture was carried out in drops of $50 \mu \mathrm{L}$ of CR2 medium plus $10 \%$ SFB under mineral oil, distributed in Petri dishes of $10 \times 35 \mathrm{~mm}$. The culture was performed in a cell culture incubator at $38.5^{\circ} \mathrm{C}, 5 \% \mathrm{CO}_{2}$ and $95 \%$ relative humidity.

The IVC of the T2, T3 and T4 treatments was performed in Nunc-type four-well plates containing $500 \mu \mathrm{L}$ of SOF medium supplemented with $2.5 \%$ FBS, under mineral oil, in groups of 30-40 structures in each well. During the whole culture, the plates containing the embryos were placed airtight bag (Aluminum Sachet) containing a gaseous mixture of $5 \% \mathrm{CO}_{2}, 5 \% \mathrm{O}_{2}$ and $90 \% \mathrm{~N}_{2}$ and saturated humidity, maintained at a temperature of $38.5^{\circ} \mathrm{C}$.

\subsection{Evaluation of Embryonic Development}

The embryo production rate and the quality of the embryos were evaluated on the eighth day of culture
(D8), using a stereoscope (Nikon SMZ 645), following the parameters described by the International Embryo Transfer Society (IETS). (Stringfellow e Seidel, 1998). The rates were evaluated under an experimental model of randomized complete blocks with five repetitions per treatment. The averages of each treatment were compared by the Ducan test at $5 \%$.

\subsection{Evaluation of eGFP Gene Expression}

The evaluation of eGFP gene expression was performed visually, in blastocysts, by means of exposure to white and ultraviolet light in stereo microscope (Nikon, SMZ800, 450-490 nm filter) or fluorescence microscope (Motic, BA400, filter 465-495 nm). In the blastocysts microinjected with the lentiviral vector, the percentage of the expression of the eGFP gene was estimated and the relative position of the fluorescence presentation was noted.

\section{Results and Discussion}

The blastocyst production rates found at D8 among the four treatments are presented in (Table 1) significant statistical differences were found $(\mathrm{p}>0.05)$ between the controls (T1, T2 and T3) but, if between the controls and $\mathrm{T} 4$ (microinjected with the lentiviral vector).

The blastocyst rates found between T1 (21.43\%) and T2 $(16.23 \%)(p>0.05)$ confirm that the atmospheric conditions and the culture medium used do not interfere with the production of blastocysts, thus, the variations found can be attributed to the self-development of embryos.

The rate of blastocysts in T3 was slightly higher than T2 ( $>>0.05$ ), which suggests that the microinjection method used in this investigation that includes perforation of the zona pellucida does not cause damage or affect embryonic development.

Only $5.26 \%$ of the oocytes treated in T4 developed until blastocyst on day eight, this percentage was significantly lower than the treatments T1, T2, and T3 (Table 1). This indicates that microinjection with the lentivirus negatively affects embryonic development, perhaps due to some factor that causes a deleterious effect on the expression of genes involved in embryonic development ${ }^{23}$.

Using the same technique of microinjection and lentiviral vector, a blastocyst rate of $22 \%$ was obtained ${ }^{19}$. A rate of $21 \%$ is presented by ${ }^{24}$ by microinjecting a retroviral vector of the Mo-MLV virus containing the envelope glycoprotein G (VSV-G) inoculated into the perithelial space 
Table 1. Production of transgenic embryos through the method of microinjection of a lentiviral vector on day eight of culture

\begin{tabular}{|c|c|c|c|c|c|c|}
\hline \multirow[t]{2}{*}{ Treatment } & \multicolumn{2}{|c|}{$\begin{array}{l}\text { Culture } \\
\text { conditions }\end{array}$} & \multirow[t]{2}{*}{$\begin{array}{l}\text { Number } \\
\text { of oocytes }\end{array}$} & \multicolumn{2}{|c|}{ Blastocysts to D8 } & \multirow{2}{*}{$\begin{array}{l}\text { Expressión } \\
\text { of eGFP gene } \\
\text { in embryons }\end{array}$} \\
\hline & $\mathrm{O}_{2}$ & Medium & & Number & $\%$ & \\
\hline T1 & $\begin{array}{l}\text { Ar } \\
\text { atm. }\end{array}$ & CR2 & 308 & 66 & $21.42^{\mathrm{a}}$ & 0 \\
\hline $\mathrm{T} 2$ & $5 \%$ & SOF & 191 & 31 & $16.23^{\mathrm{a}}$ & 0 \\
\hline T3 & $5 \%$ & SOF & 145 & 26 & $17.93^{\mathrm{a}}$ & 0 \\
\hline T4 & $5 \%$ & SOF & 190 & 10 & $5.26^{\mathrm{b}}$ & $100 \%$ \\
\hline
\end{tabular}

of the oocytes. In other species, the rates of blastocyst formation are $76 \%$ in macaque embryos microinjected with the Mo-MLV virus that contained the eGFP gene in the perivitelline space ${ }^{23}$. In pigs, a blastocyst production rate of $25 \%$ is reported by microinjecting a lentiviral vector in the perivitelline space ${ }^{25}$.

All the blastocysts obtained on day eight in the T4 treatment expressed the eGFP gene (Figure 1). The highest fluorescence was evidenced in the trophectoderm as well as in the internal cell mass of the blastocyst, confirming that this method of microinjection of the lentivirus is efficient for the incorporation of a DNA fragment in the oocyte genome.

The use of vectors derived from simple retroviruses, such as murine leukemia virus, resulted in considerable increase in gene transfer rates. However, simple retroviruses are subject to epigenetic modifications, and eventually retroviral expression can be silenced during embryonic development or shortly after birth ${ }^{23}$. In contrast, the use of lentiviral vectors resulted in high rates of transgenesis without revealing gene silencing 19 , they obtained $83 \%$ expression, and the transfer of these embryos resulted in four births. When comparing the efficiency of the lentiviral vectors derived from the feline immunodeficiency virus (FIV) and the human immunodeficiency virus (HIV) carriers of the eGFP gene, we found that the expression in stage of eight cells was significantly higher with the IVF than with HIV ( $47.5 \%$ and $22.9 \%$, respectively $)^{26}$. On the other hand, on day 7 by fertilization the eGFP gene expression rate reached 93\%, these embryos were produced by IVF with semen from a transgenic male (\# 561, Jojo) with normal females ${ }^{27}$.

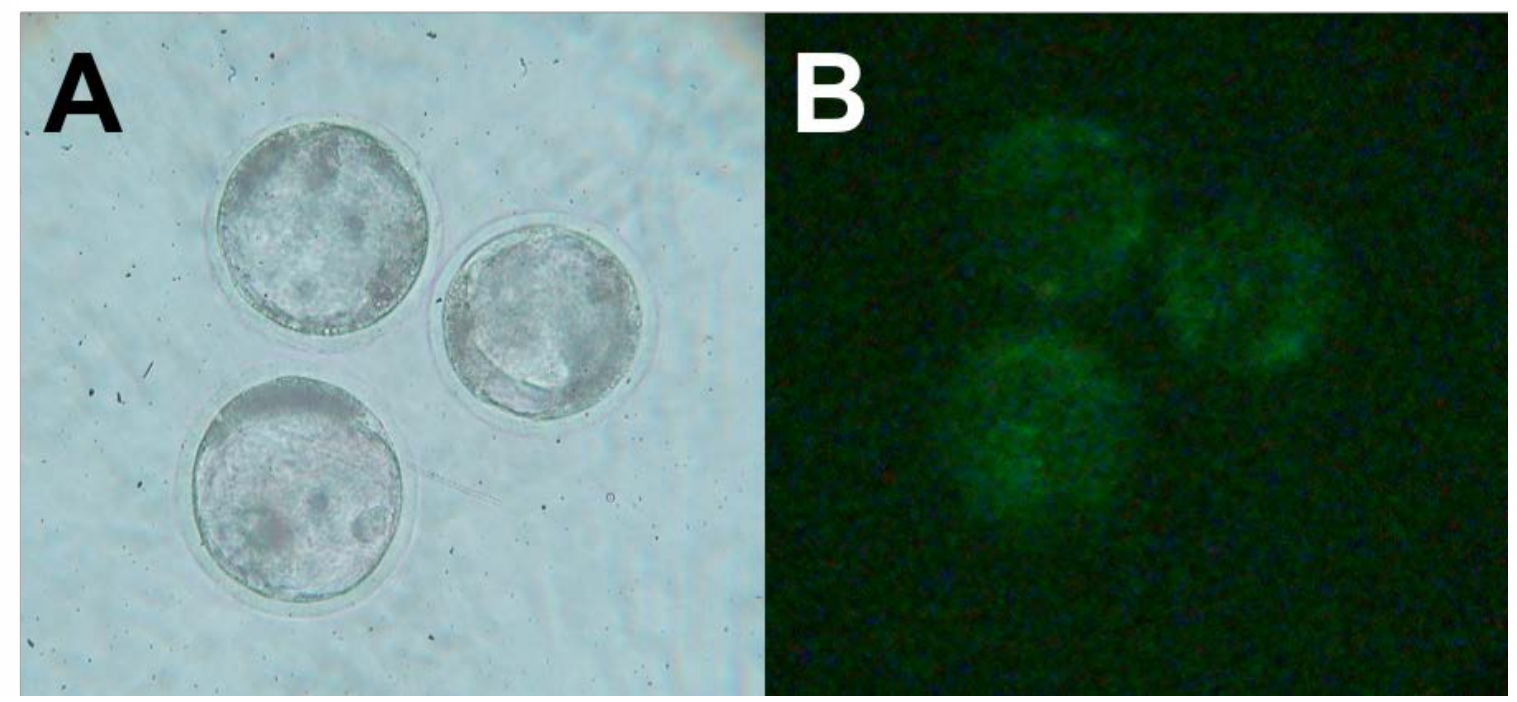

Figure 1. Bovine embryos in blastocyst stage on the eighth day microinjection with a lentiviral vector. A: Light field micrograph at 100x magnification. B: Dark field micrograph at 100x magnification, during exposure to ultraviolet radiation in the fluorescence microscope. 
In other mammalian species, mouse embryos ${ }^{28}$ report 95.5\% transgene expression. In ovines ${ }^{17}$, using a lentivirus, they found a $97.4 \%$ expression of the eGFP protein in embryos on day three, while, $28.6 \%$ is presented by ${ }^{29}$. In pigs, the expression rate of the eGFP gene varied between $70-90 \%$, using a procedure similar to the one presented here ${ }^{30}$. Variations in the transfer efficiency of the gene of interest may be due to the effect of the vector titers, virus injected volume $e^{23}$ and DNA methylation processes, which has been identified as a critical factor in the regulation of the generic expression ${ }^{31}$.

The nuclear maturation of the bovine oocytes involves the rupture of the nuclear membrane or germinative vesicle and the culmination of meiosis I until the expulsion of the second polar corpuscle, reaching the metaphase of the second meiotic division ${ }^{32-34}$. During the microinjection process, the lentiviral vectors come in contact with the chromatin, resulting in a higher probability of integrating the reporter gene into the host's genome before fertilization ${ }^{24}$. The above can explain the high percentage of transgenic embryos produced by this method.

To ensure that the infected embryonic cells are going to pass the transgenes to the daughter cells, the subzonal injection was performed or as soon as possible, which increased the possibility of producing a birth of a transgenic animal, as suggested $\frac{35}{}$, thus, the transgenic embryos, produced here, could generate transgenic animals. Additionally, this method emerges as an alternative to genetically modify animals more quickly and profitably 17,36 .

The present study provides new evidence that lentiviral transgenesis is a very efficient technology for generating transgenic animals. When compared, for example, with pronuclear microinjection of DNA $\frac{20,28,36,37}{}$ since, in ruminants, visualization of the pronucleus is difficult.

Finally, the use of simple retroviruses in transgenesis processes can activate proto-oncogenes by their insertion, which could be an initial factor for the conversion of a normal cell into a tumor cell ${ }^{28}$. Additionally, important differences were found between the preferences of integration sites in the HIV-1 and MLV viruses, demonstrating that they are preferably integrated into genomic regions surrounding the transcriptional initiation sites, especially in the promoter sequences ${ }^{3} \underline{3}$.

Therefore, the use of lentiviral vectors reduces the risk of activation of proto-oncogenes as compared to vectors derived from simple retroviruses ${ }^{39}$. Additionally, the production of high titers of lentiviral vectors does not require biosafety level confinements of more than two, even with potentially dangerous transgenes (HIV-1), due to the low volume required for microinjections $\boldsymbol{s}^{17,20}$.

\section{Conclusions}

No significant statistical differences were found in the production of blastocysts between the control treatments and the microinjections with TALP medium, indicating that the culture conditions used were adequate. The percentage of blastocysts found in the treatment microinjected with the lentivirus was significantly lower than in the other treatments, which suggests that the vector influences in some way the embryonic development, however, all the embryos that managed to continue with their development expressed the transgene of interest, indicating that the technique used here is highly efficient for obtaining transgenic embryos.

\section{Acknowledgement}

The authors thank the National Council for Scientific and Technological Development (CNPq), Foundation for Research Support of the State of Minas Gerais (FAPEMIG), Brazilian Agricultural Research Corporation (Embrapa Gado de Leite, Juiz de Fora, Brazil).

\section{References}

1. Clark A. Generation of transgenic livestock by pronuclear injection. Methods in Molecular Biology. 2002; 180: 273-87. https://doi.org/10.1385/1-59259-178-7:273

2. FELASA Working Group, Rülicke T, Montagutelli X, Pintado B, Thon R, Hedrich HJ. FELASA guidelines for the production and nomenclature of transgenic rodents. Lab Animal. 2007; 41 (3): 301-11. https://doi. org/10.1258/002367707781282758 PMid:17640457

3. Felmer R. Animales transgénicos: pasado, presente y futuro. Archivos de Medicina Veterinaria. 2004; 36 (2): 105-17. https://doi.org/10.4067/S0301-732X2004000200002

4. Monzani PS, Adona PR, Ohashi OM, Meirelles FV, Wheeler MB. Transgenic bovine as bioreactors: Challenges and perspectives. Bioengineered. 2016; 7 (3):123-31. https:// doi.org/10.1080/21655979.2016.1171429 PMid:27166649 PMCid:PMC4927206

5. Rumpf R, Melo E. Produção de animais transgênicos: metodologia e aplicações. Brasíl: Embrapa Recurso Genético e Biotecnologia. 2005; 1-27. 
6. Sosa MAG, Gasperi RD, Elder GA. Animal transgenesis: an overview. Brain Structure \& Function. 2010; 214 (2-3): 91-109. https://doi.org/10.1007/s00429-009-0230-8 PMid:19937345

7. Wheeler MB. Agricultural applications for transgenic livestock. Trends in Biotechnology. 2007; 25 (5): 204-10. https:// doi.org/10.1016/j.tibtech.2007.03.006 PMid:17379342

8. Luzardo J. El cerdo transgénico curiosidad científica o realidad médica. Academia Colombiana de Ciencias Veterinarias. 2010; 2 (1): 39-54.

9. Houdebine L-M. Transgenesis to improve animal production. Livestock Production Science. 2002; 74 (3): pp. 255-68. https://doi.org/10.1016/S0301-6226(02)00018-0

10. Ménoret S, Tesson L, Remy S, Usal C, Ouisse L, Brusselle $\mathrm{L}$, et al. Transgenic animals and genetic engineering techniques. Transgenic Research. 2015; 24 (6): 1079-85. https:// doi.org/10.1007/s11248-015-9904-6 PMid:26358113

11. Kues WA, Niemann H. Advances in farm animal transgenesis. Preventive Veterinary Medicine. 2011; 102 (2):146-56. https://doi.org/10.1016/j.prevetmed.2011.04.009 PMid:21601297

12. Chu VT, Graf R, Wirtz T, Weber T, Favret J, Li X. Efficient CRISPR-mediated mutagenesis in primary immune cells using CrispRGold and a C57BL/6 Cas 9 transgenic mouse line. National Academy of Sciences. 2016: 113 (44):125149.

13. Yum S-Y, Lee S-J, Park S-G, Shin I-G, Hahn S-E, Choi W-J. Long-term health and germline transmission in transgenic cattle following transposon-mediated gene transfer. BMC Genomics. 2018; 19 (1): 1-387. https://doi.org/10.1186/ s12864-018-4760-4 PMid:29792157 PMCid:PMC5966871

14. Tenório L, Silva F, Han S. A Potencialidade dos Lentivetores na Terapia Gênica. Revista Brasileira Clinica Médica. 2008; $6(6): 260-7$.

15. Wang Y, Song Y, Liu Q, Liu C, Wang L, Liu Y. Quantitative analysis of lentiviral transgene expression in mice over seven generations. Transgenic Research. 2010; 19 (5): 775-84. https://doi.org/10.1007/s11248-009-9355-Z PMid:20091347

16. Prasher DC, Eckenrode VK, Ward WW, Prendergast FG, Cormier MJ. Primary structure of the Aequorea victoria green-fluorescent protein. Gene. 1992; 111 (2): 229-33. https://doi.org/10.1016/0378-1119(92)90691-H

17. Crispo M, Vilari-o M, Santos-Neto PC dos, Nú-ez-Olivera R, Cuadro F, Barrera N, et al. Embryo development, fetal growth and postnatal phenotype of eGFP lambs generated by lentiviral transgenesis. Transgenic Research. 2015; 24 (1):31-41. https://doi.org/10.1007/s11248-014-9816-X PMid:25048992

18. Lois C, Hong EJ, Pease S, Brown EJ, Baltimore D. Germline transmission and tissue-specific expression of trans- genes delivered by lentiviral vectors. Science. 2002; 295 (5556): 868-72. https://doi.org/10.1126/science.1067081 PMid:11786607

19. Hofmann A, Zakhartchenko V, Weppert M, Sebald H, Wenigerkind H, Brem G. Generation of transgenic cattle by lentiviral gene transfer into oocytes. Biology of Reproduction. 2004; 71 (2):405-9. https://doi.org/10.1095/ biolreprod.104.028472 PMid:15044266

20. Miao K, Guo M, An L, Xu XL, Wu H, Wang D. A new method to efficiently produce transgenic embryos and mice from low-titer lentiviral vectors. Transgenic Research. 2011; 20 (2):357-63. https://doi.org/10.1007/s11248-0109414-5 PMid:20585977

21. Van Soom A, Wrathall AE, Herrler A, Nauwynck HJ. Is the zona pellucida an efficient barrier to viral infection? Reproduction, Fertility and Development. 2010; 22 (1):2131. https://doi.org/10.1071/RD09230 PMid:20003842

22. Samaniego J, Ayala L, Nieto P, Rodas R, Vázquez J, Murillo Y. Competencia del ovocito bovino obtenido por Ovum pick-up valorado mediante el azul brillante de Cresilo. Maskana. 2017; 8:77-80.

23. Chan AW, Chong KY, Martinovich C, Simerly C, Schatten G. Transgenic monkeys produced by retroviral gene transfer into mature oocytes. Science. 2001; 291 (5502):309-12. https:// doi.org/10.1126/science.291.5502.309 PMid:11209082

24. Chan AW, Homan EJ, Ballou LU, Burns JC, Bremel RD. Transgenic cattle produced by reverse-transcribed gene transfer in oocytes. National Academy of Sciences USA. 1998; 95 (24):14028-33. https://doi.org/10.1073/ pnas.95.24.14028

25. Hofmann A, Kessler B, Ewerling S, Weppert M, Vogg B, Ludwig H. Efficient transgenesis in farm animals by lentiviral vectors. EMBO Reports. 2003; 4 (11):1054-60. https://doi.org/10.1038/sj.embor.7400007 PMid:14566324 PMCid:PMC1326377

26. Xu Y-N, Uhm S-J, Koo B-C, Kwon M-S, Roh J-Y, Yang J-S. Production of Transgenic Korean Native Cattle Expressing Enhanced Green Fluorescent Protein Using a FIV-Based Lentiviral Vector Injected into MII Oocytes. Journal of Genetics and Genomics. 2013; 40 (1):37-43. https://doi. org/10.1016/j.jgg.2012.11.001 PMid:23357343

27. Reichenbach $M$, Lim T, Reichenbach H-D, Guengoer T, Habermann FA, Matthiesen M. Germ-line transmission of lentiviral PGK-EGFP integrants in transgenic cattle: new perspectives for experimental embryology. Transgenic Research. 2010; 19 (4):549-56. https://doi.org/10.1007/ s11248-009-9333-5 PMid:19862638

28. Pfeifer A, Ikawa M, Dayn Y, Verma IM. Transgenesis by lentiviral vectors: lack of gene silencing in mammalian embryonic stem cells and preimplantation embryos. National Academy of Sciences USA. 2002; 99 (4):2140-5. 
https://doi.org/10.1073/pnas.251682798 PMid:11854510 PMCid:PMC122332

29. Liu C, Wang L, Li W, Zhang X, Tian Y, Zhang N. Highly Efficient Generation of Transgenic Sheep by Lentivirus Accompanying the Alteration of Methylation Status. PLOS ONE. 2013; 8 (1):e54614. https://doi.org/10.1371/journal. pone.0054614 PMid:23382924 PMCid:PMC3558511

30. Singer O, Verma IM. Applications of lentiviral vectors for shRNAdeliveryand transgenesis. CurrentGeneTherapy.2008; 8 (6):483-8. https://doi.org/10.2174/156652308786848067 PMid:19075631 PMCid:PMC2774780

31. Tian Y, Li W, Wang L, Liu C, Lin J, Zhang X. Expression of $2 \mathrm{~A}$ peptide mediated tri-fluorescent protein genes were regulated by epigenetics in transgenic sheep. Biochemical and Biophysical Research Communications. 2013; 434 (3):681-7. https://doi.org/10.1016/j.bbrc.2013.04.009 PMid:23603255

32. Kim VN, Mitrophanous K, Kingsman SM, Kingsman AJ. Minimal requirement for a lentivirus vector based on human immunodeficiency virus type 1. Journal of Virolog. 1998; 72 (1):811-6. PMid:9420292 PMCid:PMC109441

33. Otero R. Classificação de Ovocitos Imaturos de Bovinos pela Utilização do Azul Cresil Brilhante. Universidade Federal de Viçosa, (Tesis de Mestrado - Medicina Veterinária Viçosa-MG, Brasil. 2008
34. Otero R, Costa P, Pereira M. Maturação nuclear in vitro de ovócitos bovinos selecionados pelo método azul cresil brilhante. Revista Colombiana de Ciencia Animal. 2017; 9 (2):345-54. https://doi.org/10.24188/recia.v9.n2.2017.617

35. Pfeifer A. Lentiviral transgenesis. Transgenic Research. 2004; 13 (6): 513-22. https://doi.org/10.1007/s11248-0042735-5 PMid:15672832

36. Park F. Lentiviral vectors: are they the future of animal transgenesis? Physiological Genomics. 2007; 31 (2):15973. https://doi.org/10.1152/physiolgenomics.00069.2007 PMid:17684037

37. Wassarman P, Soriano P. Guide to Techniques in Mouse Development, Part B. Mouse Molecular Genetics. 1st Edition. 2010; 477:1-628.

38. Wu X, Li Y, Crise B, Burgess SM. Transcription start regions in the human genome are favored targets for MLV integration. Science. 2003; 300 (5626):1749-51. https://doi. org/10.1126/science.1083413 PMid:12805549

39. Follenzi A, Ailles LE, Bakovic S, Geuna M, Naldini L. Gene transfer by lentiviral vectors is limited by nuclear translocation and rescued by HIV-1 pol sequences. Nature Genetics. 2000; $25 \quad$ (2):217-22. https://doi.org/10.1038/76095 PMid:10835641 